\title{
Water chemistry analysis in the sediment of Baradla Cave, Hungary
}

\author{
Edit Borbás*, József Kovács \\ Department of Physical and Applied Geology, \\ Eötvös Loránd University, Budapest \\ Katalin Fehér \\ Department of Environmental and Landscape \\ Geography, Eötvös Loránd University, Budapest
}

\author{
Gábor Vid \\ Niphargus Cave Research Group, Jósvafő \\ István Gábor Hatvani \\ Department of Physical and Applied Geology, \\ Eötvös Loránd University, Budapest
}

\begin{abstract}
Water was observed in the sediment of Baradla Cave, located in Northeast Hungary. In order to investigate its characteristics wells were drilled. Hydrochemical samples were taken directly from the wells and from the cave stream on several occasions between November 2009 and April 2010. In February 2010 there was an opportunity to observe how the chemical composition of the waters of the creeks and the sediments altered during the snow melt. Several chemical parameters of the samples were analyzed. Based on the results of the hydrochemical analyses cluster analysis was applied to define the relationship between the sampling points. Discriminant analysis was conducted to verify the classification. As a result of the classification, the water of the observation wells in the sediment proved to be distinct from the water of the cave's creek and the springs on the surface.

Research shows that there is no permanent connection between the water in the cave sediment and the water of the cave creek in the cave water system.
\end{abstract}

Key words: Baradla Cave, water in the sediment, separated water system

\section{Introduction}

The Baradla Cave is located in Northeast Hungary, in the Aggtelek National Park (Fig. 1). The cave, Aggtelek and its surroundings were listed as a part of the World Cultural and Natural Heritage by UNESCO in 1995. The Baradla Cave has been protected by the Ramsar Convention since 2001.

\footnotetext{
Addresses: E. Borbás, J. Kovács, I. G. Hatvani: H-1117 Budapest, Pázmány P. stny. 1/c, Hungary

G. Vid: H-3758 Jósvafő, Kaffka Péter u. 4, Hungary

K. Fehér: H-1117 Budapest, Pázmány P. stny. 1/c, Hungary

*Corresponding author; e-mail: borbas_edit@hotmail.com

Received: August 28, 2010; accepted: January 24, 2012
} 
The Baradla-Domica Cave System has a Hungarian $(21 \mathrm{~km})$ and a Slovakian part $(6 \mathrm{~km})$. The Hungarian part is Baradla Cave itself and the Slovakian part is Domica Cave. There are natural entrances in Hungary, near the village of Aggtelek, while the Slovakian natural entrances are very close to the village of Domica; this made it possible for prehistoric people to utilize the cave. Tourism started in the 1760s in the Aggtelek section. Research and excavations began in 1801. The most significant researcher was Imre Vass, who excavated the greater part of the main branch of the cave between 1821 and 1825 . He documented the excavation, and his book (published in 1831) still forms the basis of research on Baradla Cave (Vass 1831). Hydrological research of the cave system was begun by Hubert Kessler in the early 20th century. He recognized that there are deeper routes under the cave, which he named as the Lower Cave (Kessler 1938). László Jakucs began studying the cave in the 1950s (Jakucs 1951). In 1955 there was a turning point in the history of the recognition of the cave when, after a flood, the cave, which was supposed to consist of one cave, actually turned out to consist of two separate caves. In the same year scientists were able to pass through the spring mouth into the cave, which was almost completely filled with water. This cave is now known as the Short Lower Cave. In the early 1980s a $1 \mathrm{~km}$-long section was explored. At the end of the 20th century a $150 \mathrm{~m}$-long section of Long Lower Cave was explored and studied. Numerous water tracing experiments completed in the 1970-1980s allowed the hydrological separation and length determination of these two lower caves.

In 2002 a research team studied the several meter-thick cave sediment. During sampling of the cave sediment (carried out by manual drilling), water was observed. With casing and filtering, the drills were able to monitor the water level. As a result, the water in the cave sediment was also observable and could be compared over a long time scale. In 2006, water level recording began in the

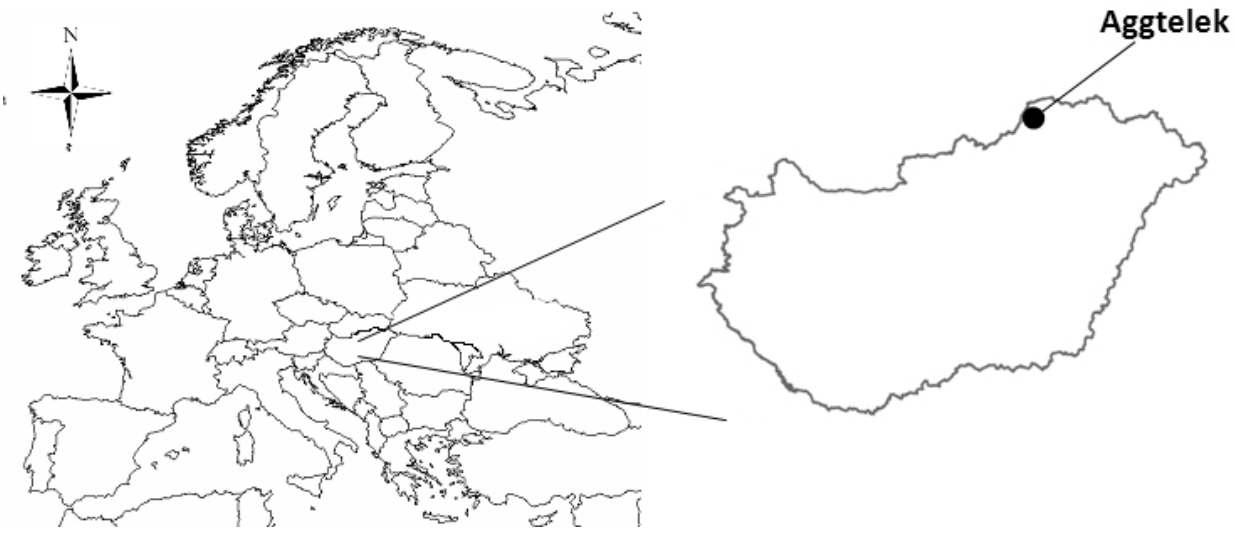

Fig. 1

Location of the studied cave 


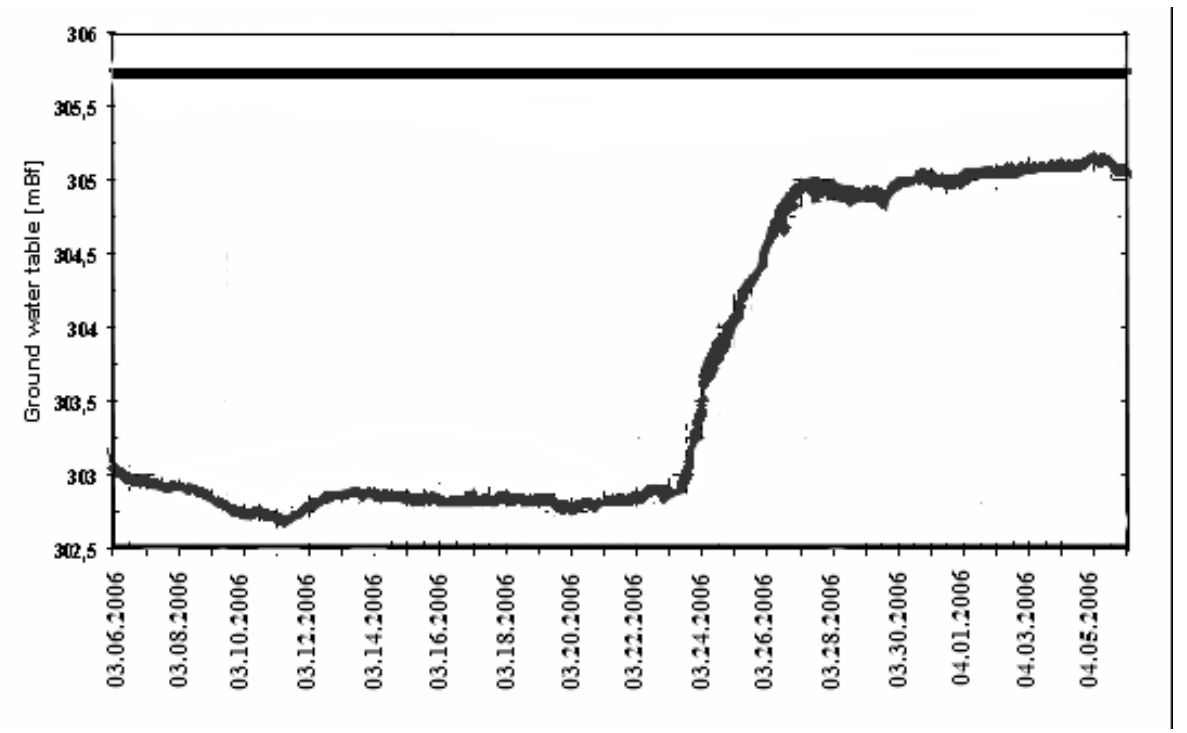

Fig. 2

The effect of spring snowmelt on the water level of the Olympos well in 2006 (Berényi et al. 2006) (the straight line shows the level of the terrain $-\mathrm{mBf}=$ meters above Baltic Sea level)

observation well (Olympos well) (Fig. 2). Due to the spring snow melt the water level rose 2 meters in 4 days, indicating a connection between the water in the cave sediment and the weather processes above ground (Berényi et al. 2006).

The chemical parameters of the water in the cave sediment, creek and springs were studied spatially and temporally using the multi-variant statistical methods of cluster analysis and multidimensional scaling.

\section{Geologic and hydrological description of the cave}

Baradla Cave is located in the southern partof the Gömör-Torna Karst. The main body of the mountain consists of Triassic marine limestone. The karstified mountain is partly overlain by Pannonian sediment and partly uncovered. The mountain was tectonically active for a long time; therefore the bedrock is strongly crumbled, which played a major role in the formation of the cave (Gyuricza et al. 2003).

The evolution of the cave began in the Mindel-Riss interglacial stage (Gyuricza and Sásdi 2009). Based on the examination of the stalactites in the cave the main branch is at least 150,000 years old. Its size had not changed since the last interglacial stage (Zámbó et al. 2002). Several periods can be identified in the evolution (Fig. 3). First, water in the tectonic fissures expanded the cavern by mixture corrosion. The cave was filled to the roof with sediment brought here by the water. This sediment was transported by water from the surface; it consists 


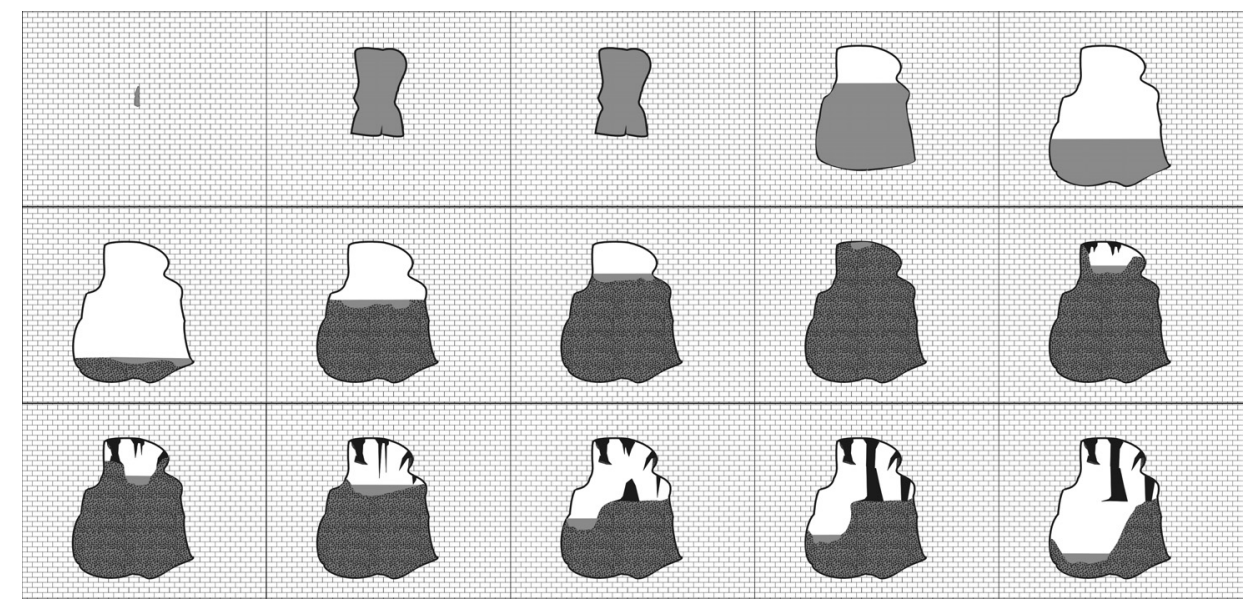

Fig. 3

The evolution of the cave (Berényi et al. 2006), showing how it was filled up with sediment and how the sediment was transported from the cave by the floods of the creeks

mostly of sand, gravel and silt. Later, the runoff from the creeks increased and started to erode the cave walls vertically and so remove sediment from the passages. This filling-erosion cycle may have been repeated several times. Sediment deposition can still be observed at present (Berényi et al. 2006).

The area of the cave system's watershed exceeds $34 \mathrm{~km}^{2}$. Beside the infiltration, rainwater reaches the cave through surface sinkholes located in the covered karst. These sinkholes are associated with the cave's side branches. Thanks to the sinkholes and the infiltration from the surface, water recharge into the cave is almost constant. However, flowing water cannot usually be observed in the cave because of the cave sinkholes in the main branch, which lead to the Lower Cave. The water of the cave system reaches the surface through Jósva Spring, which is, with its two spring mouths, the largest karst spring in the area. One of the spring mouths is Táró Spring, which brings the Short Lower Cave's water to the surface, and the other is Medence Spring, which brings the Long Lower cave's water to the surface. The average discharge of Jósva Spring is over $14,000 \mathrm{~m}^{3}$ a day.

\section{Sediment composition}

Samples from the observation wells (Olympos well, Styx well) drilled into the cave-sediment were processed using particle-size distribution and X-ray diffraction. In the Olympos observation well, based on pumping test results, the permeability coefficient was estimated at $10^{-6} \mathrm{~m} / \mathrm{s}$. According to Freeze and Cherry (1979) this aquifer value indicates silty sand. Based on the granulometric composition measurements the main mineral component of the sediment in 
Baradla Cave is quartz, with only minor quantities of other minerals present. The character of the sediment indicates a not too distant metamorphic denudation area (Berényi et al. 2006). Figure 4 shows the sediment characteristics of the observation wells.

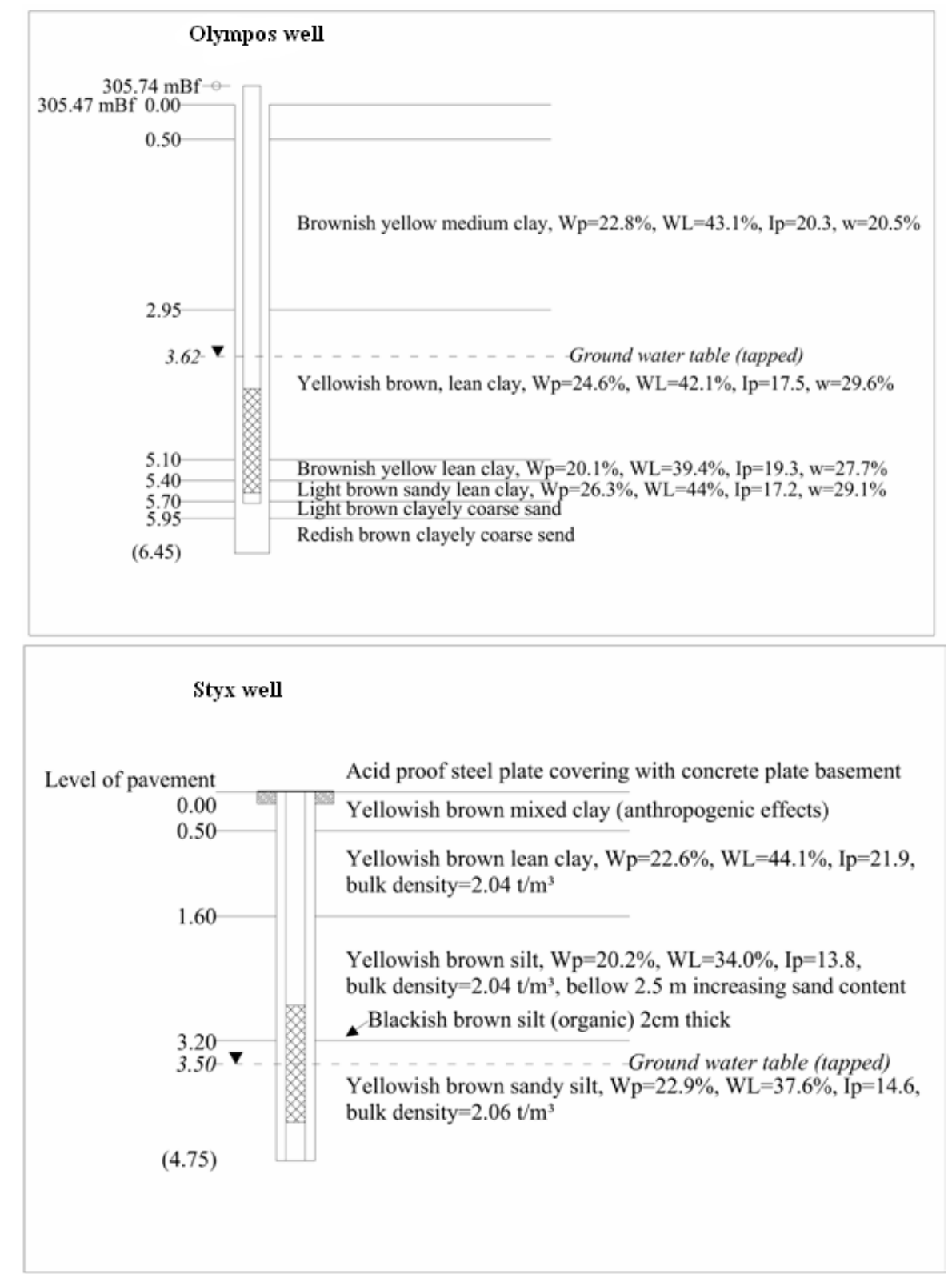

Fig. 4

Sediment characteristics of the Olympos and the Styx wells (Berényi et al. 2008) (mBf=meters above Baltic Sea level) 


\section{Measuremet methodology}

Sampling locations

Between November 2009 and April 2010 water samples were taken ten times from six areas.

From the surface we took samples from Jósva Spring (Táró and Medence Springs), which brings the cave system's water to the surface. In addition we had four other sampling locations within the cave (Fig. 5).

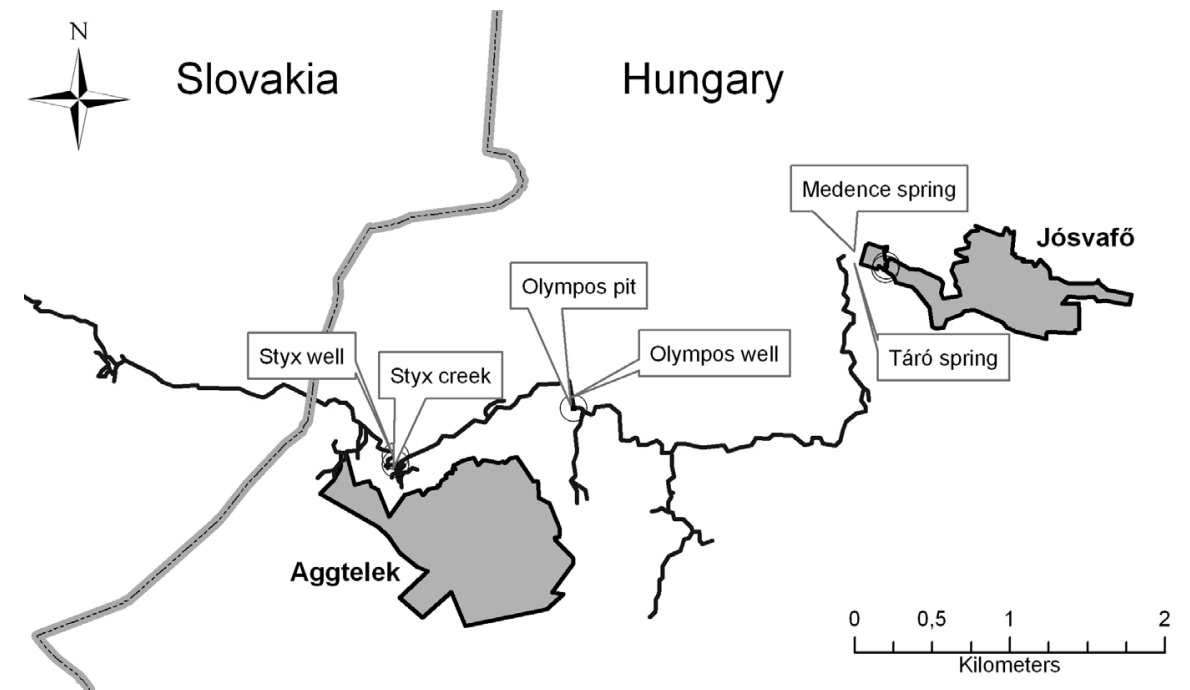

Fig. 5

Location of the sampling points

The samples in the cave were taken from the creek and also from the drilled wells from the following locations:

- The Styx well (Fig. 6): a drilled observation well in a side branch leading to the Styx creek. This area is in a section of the cave near the village of Aggtelek. The depth of the well is $4.75 \mathrm{~m}$ (Fig. 4). Water is not continuously present; periodically the well dries up.

- The Styx creek: this is the main watercourse of Baradla Cave and comes from Slovakia. An active watercourse can be observed in this section of the cave most of the year. The distance between the Styx creek and the Styx well is $30 \mathrm{~m}$. Despite the short distance, the creek's effect on the water level in the well could not be proven. The reason for this is the low permeability coefficient.

- The Olympos well: this is $2.2 \mathrm{~km}$ from the Aggtelek entrance; its depth is $6.45 \mathrm{~m}$ (Fig. 4).

- The Olympos pit: this is $2 \mathrm{~m}$ from the observation well. It was dug in the second half of the 1980s for geologic sampling purposes. Water appeared in the 


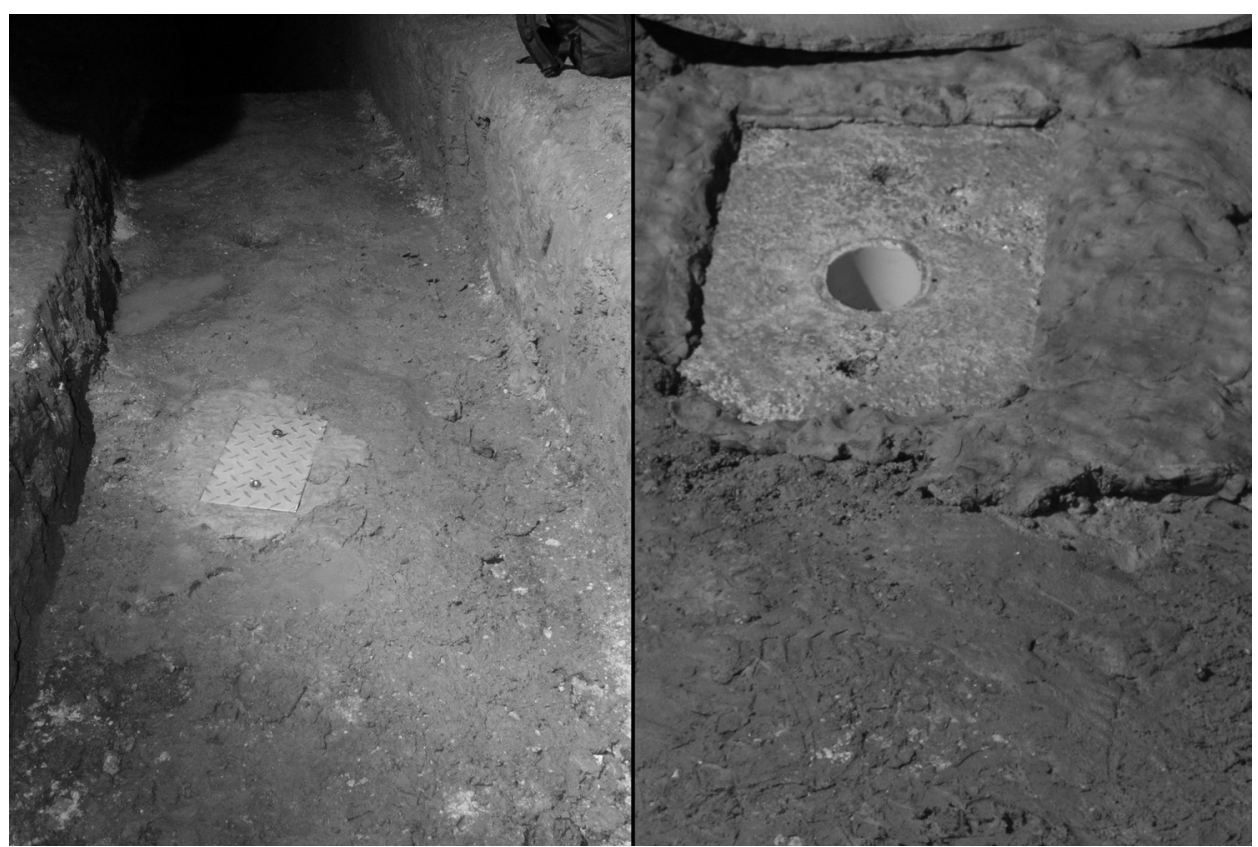

Fig. 6

Styx well closed and open

pit a few years after it was dug; this water is presumably leaking water accumulated on the sediment surface. In order to observe the change of water level a gauge was deployed during the drilling. During the sampling, the water level was constantly monitored.

\section{Hydrochemical analyses}

Laboratory examinations of the water samples were conducted according to Hungarian standards for the following parameters: water temperature $\left(0^{\circ} \mathrm{C}\right)$, electrical conductivity $\left(\mathrm{mS} \mathrm{cm}^{-1}\right), \mathrm{Ca}^{2+}, \mathrm{Mg}^{2+}, \mathrm{Na}^{+}, \mathrm{K}^{+}, \mathrm{HCO}_{3}{ }^{-}, \mathrm{SO}_{4}{ }^{2-}, \mathrm{NO}_{3}{ }^{-}$, Total Dissolved Solids - TDS (mg L${ }^{-1}$ ), $\mathrm{pH}$. The $\mathrm{Ca}^{2+}, \mathrm{Mg}^{2+}$ and $\mathrm{HCO}_{3}{ }^{-}$contents were determined by titration, the $\mathrm{SO}_{4}{ }^{2-}$ and $\mathrm{NO}_{3}{ }^{-}$contents by spectrometry, and the $\mathrm{Na}+$ and $\mathrm{K}+$ contents by flame photometry.

\section{Results and discussion}

Following analysis of the 56 samples the descriptive statistics of the measured parameters were assembled for all the sampling points; the median values can be seen in Table 1. 
Table 1

Median values of the chemical parameters

\begin{tabular}{|l|c|c|c|c|r|r|r|r|r|r|}
\hline & $\begin{array}{c}\text { TDS } \\
\mathrm{mg} \mathrm{L}^{-1}\end{array}$ & $\begin{array}{c}\text { Conductivity } \\
\mathrm{mS} \mathrm{cm}\end{array}$ & $\mathrm{pH}$ & $\begin{array}{c}\mathrm{Ca}^{2+} \\
\mathrm{mg} \mathrm{L}^{-1}\end{array}$ & $\begin{array}{c}\mathrm{Mg}^{2+} \\
\mathrm{mg} \mathrm{L}^{-1}\end{array}$ & $\begin{array}{c}\mathrm{HCO}_{3}^{-} \\
\mathrm{mg} \mathrm{L}^{-1}\end{array}$ & $\begin{array}{c}\mathrm{SO}_{4}{ }^{2-} \\
\mathrm{mg} \mathrm{L}^{-1}\end{array}$ & $\begin{array}{c}\mathrm{NO}_{3}^{-} \\
\mathrm{m} \mathrm{L}^{-1}\end{array}$ & $\begin{array}{c}\mathrm{Na}^{+} \\
\mathrm{mg} \mathrm{L}^{-1}\end{array}$ & $\begin{array}{c}\mathrm{K}^{+} \\
\mathrm{mg} \mathrm{L}^{-1}\end{array}$ \\
\hline Táró spring & 536 & 609 & 7.8 & 118.2 & 7.3 & 363.4 & 34.4 & 3.8 & 1.2 & 0.5 \\
Medence spring & 554 & 630 & 7.2 & 116.2 & 12.2 & 376.4 & 35.7 & 4.1 & 1.2 & 0.9 \\
\hline Styx creek & 586 & 665 & 7.8 & 125.7 & 9.5 & 389.4 & 48.4 & 3.8 & 1.3 & 0.6 \\
\hline Styx well & 393 & 474 & 7.8 & 86.4 & 7.3 & 240.1 & 54.7 & 3.2 & 0.7 & 1.1 \\
Olympos pit & 464 & 523.5 & 8.1 & 106.2 & 5.5 & 324.5 & 24.9 & 1.3 & 0.9 & 0.3 \\
\hline Olympos well & 369 & 425 & 7.9 & 80.2 & 16.3 & 236.9 & 29.2 & 4.6 & 0.9 & 0.5
\end{tabular}

The conductivity values in the observation wells sunk in the cave sediment are significantly lower than the ones at the other measurement locations due to the lower $\mathrm{Ca}^{2+}$ and $\mathrm{HCO}_{3}{ }^{-}$contents. Regarding the other parameters, significant differences cannot be observed between the leaking water in the sediment, the cave creek, and the springs.

Previous studies had already showed that the main components of the water of Baradla Cave are calcium, bicarbonate and magnesium (Izápy and Maucha 2002). As expected, based on the average values of the hydrochemical parameters the water of the cave is considered to be in the calcium-magnesium-bicarbonate hydrochemical facies (Back 1966) (Table 1; Fig. 7). Differences cannot be observed between the sampling locations, considering the joint effect of the parameters in the Piper diagram (Fig. 7).

Considering the temporal variability of the parameters measured at the sampling locations, significant changes were noticed in the chemical characteristics of the water samples in February 2010, when there was a remarkable snow melt in the cave's watershed area. Previously similar changes were noticed in the water of Béke Cave near Baradla Cave, when a flood occurred in the area (Telbisz et al. 1999).

Due to the melt water, the TDS value decreased primarily in the cave creek and the springs (Fig. 8), and after the effect of melt waters had passed the TDS values rose to the level at which they were before the flood.

In the case of the cave sediment sampling locations the TDS values did not change or the changes were not considerable.

The biggest difference (close to $70 \%$ ) was observed in the data set of the Styx Creek and Táró Spring. In the Styx Creek the TDS was $595 \mathrm{mg} \mathrm{L}^{-1}$ before the flood (February 13, 2010), and one week later (February 20, 2010) this value had decreased to $182 \mathrm{mg} \mathrm{L}^{-1}$. In the case of Táró spring the values were the following: $587 \mathrm{mg} \mathrm{L}^{-1}$ (before the flood), and $174 \mathrm{mg} \mathrm{L}^{-1}$ (after the flood).

The snow melt had a significant effect on the water level of the observation wells in the cave (Fig. 9). The water level rose by 1-1.5 $\mathrm{m}$ and decreased more slowly in comparison (over a couple weeks) to the normal level. 
Fig. 7

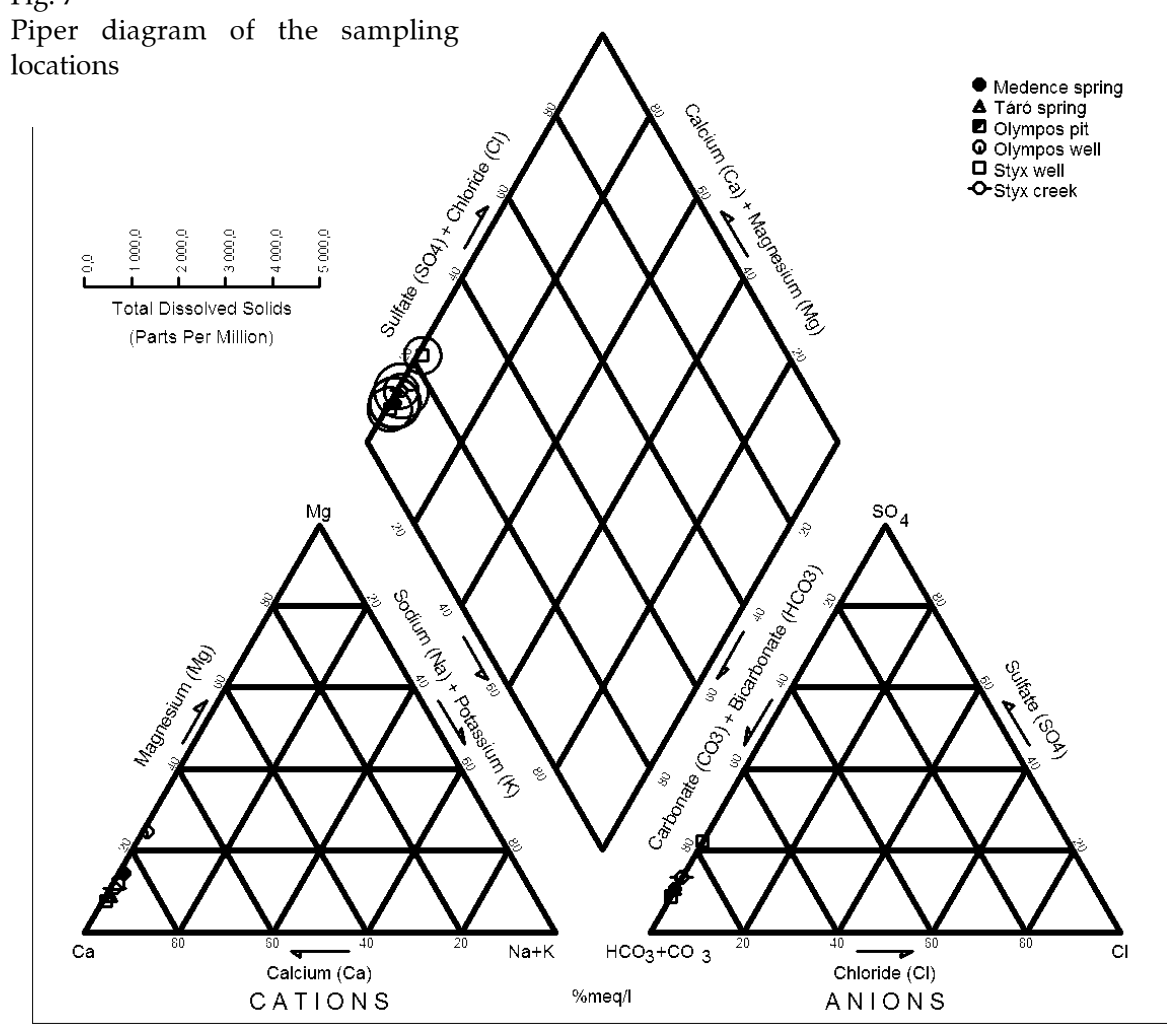

The analysis of the TDS from all sampling locations for the total measured period clearly shows that the TDS in the observation wells is originally lower than in the cave's other observed locations (Táró and Medence Springs, Styx Creek) (Table 1). Comparing the data (Table 1; Figs 8 and 9) we concluded that the melt water had the greatest effect on the configuration of the water's chemical characteristics in the observation wells.

\section{Statistical methods}

The results of the hydrochemical analyses allowed us to compare the sampling locations using all measured parameters. To do this we used hierarchical cluster analysis. Its result is a dendrogram where the analyzed objects are on the horizontal axis, and the linkage distance is on the vertical axis. The result needs to be checked by hypothesis testing; for this Discriminant Analysis was used.

Cluster analysis was applied to the characteristic parameters of the 6 sampling locations for every sampling point in time. In both cases, Discriminant Analysis was used to check the classification. The results of these two applications were $100 \%$ and $95 \%$. 


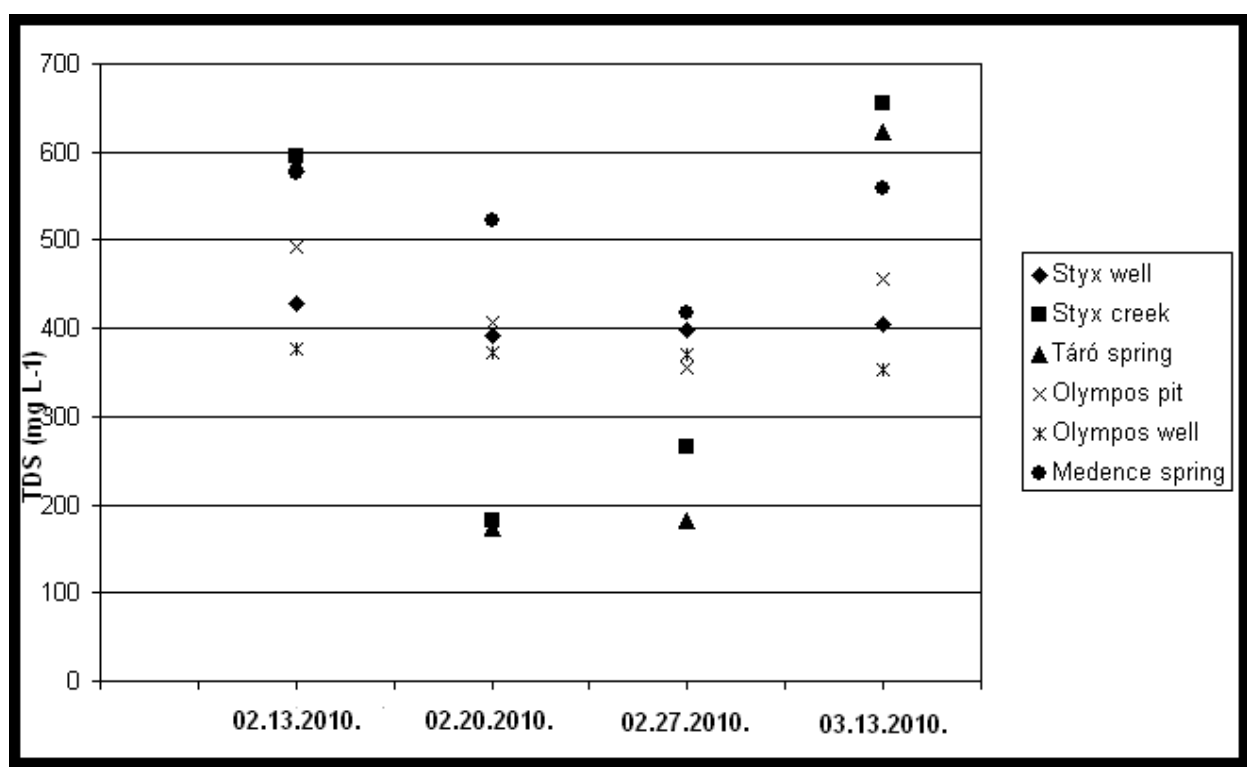

Fig. 8

Total Dissolved Solids' values of the samples after snow melt in February 2010

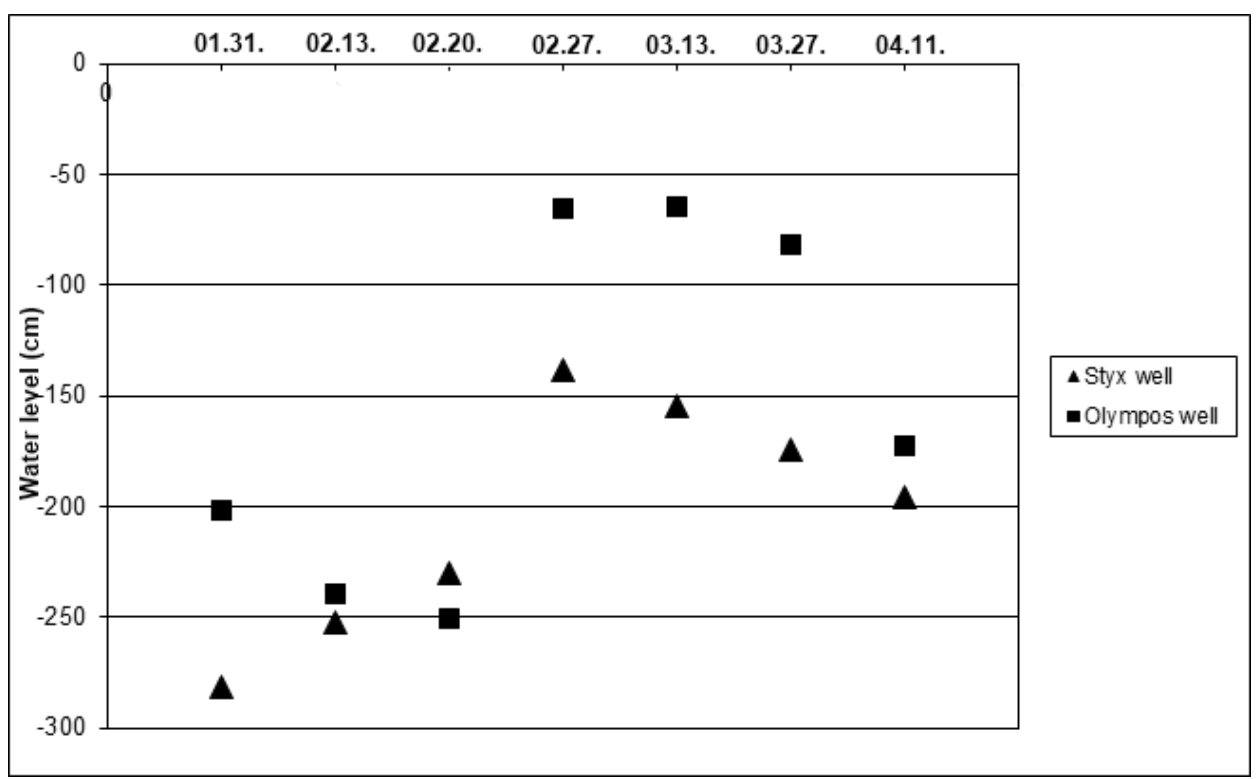

Fig. 9

Groundwater levels in the observation wells between January 31, 2010 and April 11, 2010 
In the first case, two clusters were noticed at a Linkage Distance of 28 (Fig. 10). Group I contains three sampling points, the two observation wells (the Styx and Olympos wells) and the Olympos pit. Group II contains the Styx Creek, and Táró and Medence Springs. This result means that the chemical characteristics of water in the sediment are different from those of the cave creek).

In the second case, two groups were identified at a Linkage Distance of 150 (Fig. 11). Group 1 contains the samples taken from the three sampling locations

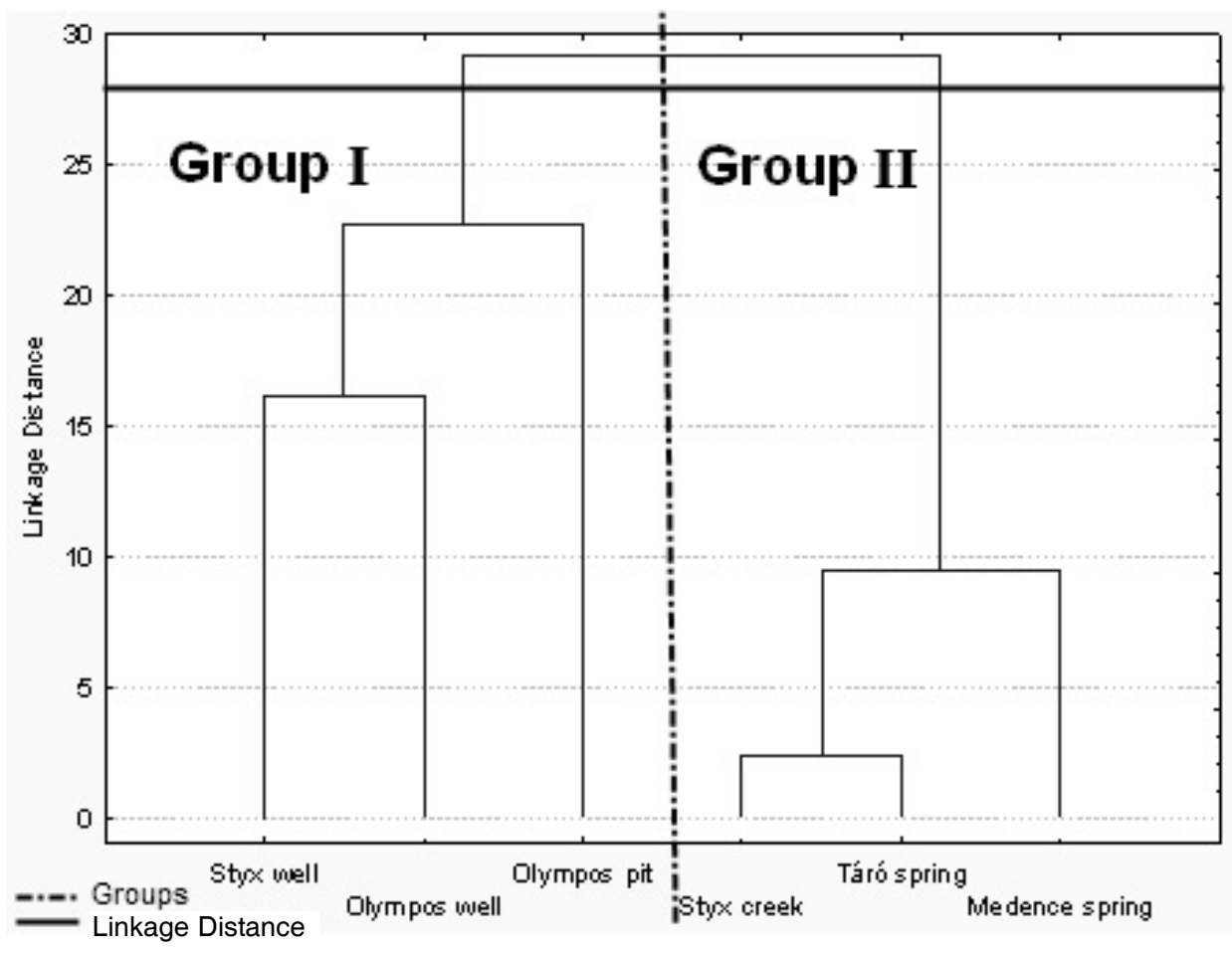

Fig. 10

Dendrogram of the characteristic parameters of the sampling locations

settled in the sediment (as in Fig. 10) and the samples taken from the springs and creek when their waters had been diluted by floods, while Group 2 contains the samples from the springs and creek, just as in Figure 8.

The descriptive statistics of these two groups were plotted on box-and-whisker diagrams. The bottom of the box represents the lower quartiles (the 25th percentile) and the top the upper quartiles (the 75th percentile). Half of the data is located in the box. The band in the box represents the median (the 50th percentile). Any data not included between the whiskers is plotted as an outlier with small circle or star (Norusis 1993). 


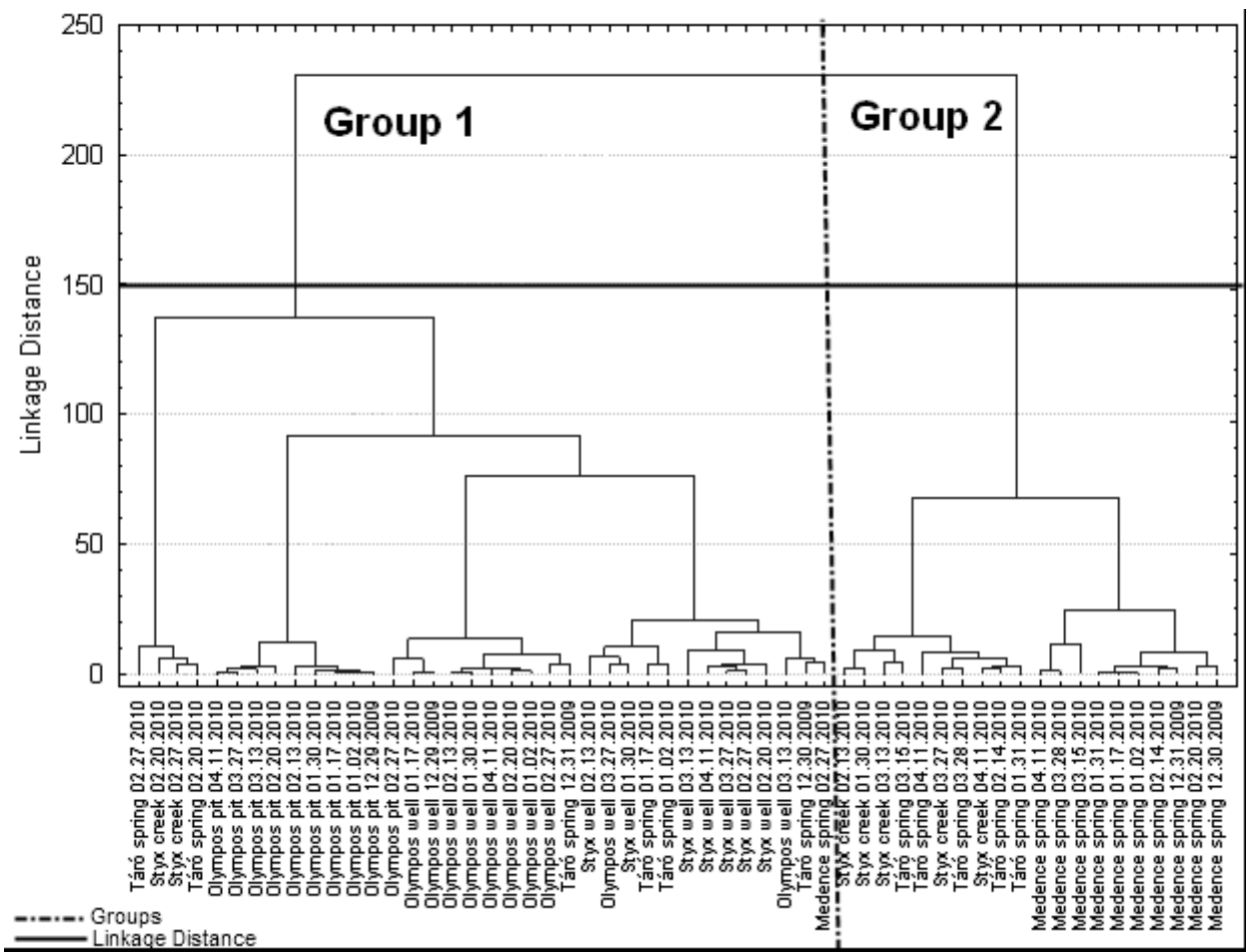

Fig. 11

Dendrogram of each sampling in time

Group 1 indicates a lower concentration for all parameters except $\mathrm{pH}$. Chemical characteristics of the water in the cave-sediment indicate lower concentration and permanency (Fig. 12). This water leaks into the sediment during melting, and retains its characteristics during its stay there.

\section{Summary}

Water was observed in the sediment of Baradla Cave located in Northeast Hungary. In order to observe its characteristics wells were sunk into the sediment. Hydrochemical analyses were conducted on samples taken directly from the wells and from a cave creek and surface springs on several occasions.

Water samples could be classified into the calcium-magnesium-bicarbonate hydrochemical facies, as had been expected. The hydrochemical analyses were begun in November 2009 and finished in April 2010. As a result there was an opportunity to observe if and how the chemical contents of the creek and sediment water changed during the snowmelt. The water level values in the wells increased after one week, while the TDS of the surface springs and cave creek decreased. In the samples obtained from the observation wells this change 
Water chemistry analysis in the sediment of Baradla Cave, Hungary 379

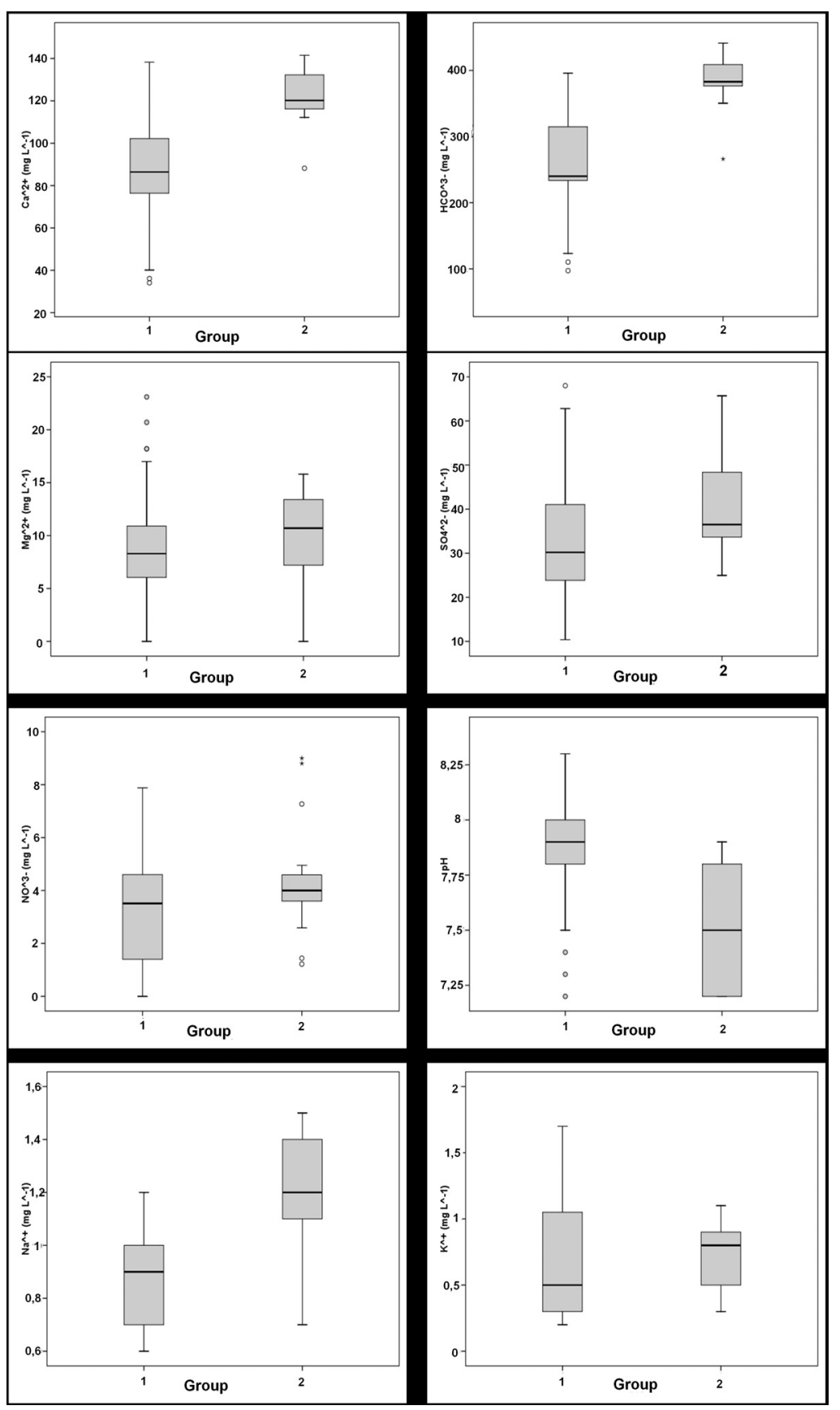

Fig. 12

Box-and-whisker diagrams of Groups 1 and 2 made from each sampling in time 
was not noticeable. The observation wells in the cave sediment are filled with water whenever a flood occurs and their chemical characteristics do not change even after the flood. Comparing the observation wells to other cave observation locations it is observed that the TDS values are originally low due to diluted meltwater, and the fact that the main ingredient of the cave sediment is quartz. Therefore dissolution is minimal in the rock-water interaction.

Karst dissolution is the main process that determines the chemical characteristics of cave creek and springs. During floods it can change significantly (the floodwater dilutes it to a high degree). And after the flood has receded the chemical content settles back to its previous state.

Research shows that there is no permanent connection between the water in the cave sediment and the water of the cave creek in the cave water system.

\section{References}

Back, W. 1966: Hydrochemical facies and ground-water flow patterns in northern part of Atlantic Coastal Plain. - U.S. Geol. Surv. Prof. Paper 498-A., 42 p.

Berényi Üveges, I., J. Berényi Üveges, G. Vid 2006: Adalékok a Baradla-barlang fejlődésének elméletéhez üledék vizsgálatok alapján (The evolution of the Baradla cave on the basis of sediment analysis). - Karszt és Barlang, 2006/1-2, pp. 33-40.

Berényi Üveges, J., G. Vid, I. Berényi Üveges 2008: Sediments and groundwater in the Baradla and Béke caves, Hungary. - 4th European Speleological Congress, Vercors, France.

Freeze, R.A., J.A. Cherry 1979: Groundwater. - Prentice Hall. Engwood Cliffs. New Jersey, 29 p.

Gyuricza, Gy., O. Piros, O., F. Szilágyi, G. Salamon 2003: Baradla-barlangrendszer (Baradla cave system). - In: Székely, K.: Magyarország fokozottan védett barlangjai, Budapest, pp. 26-36.

Gyuricza, Gy., L. Sásdi 2009: A Baradla-barlangrendszer kialakulásának kérdései a tágabb környezet földtani fejlődésének tükrében (Theory of the evolution of the Baradla Cave as mirrored in the geological evolution of its neighbourhood). - Földtani Közlöny, 139/1, pp. 83-92.

Izápy, G., L. Maucha 2002: Az Aggteleki-hegység karszthidrológiai vizsgálata a jósvafői Kutatóállomáson (Karst hydrology analysis of Aggtelek Karst on Jósvafő Research Station). - A karsztvízkutatás Magyarországon - bükki karsztvízkutatás legújabb eredményei c. konferencia kiadványa. Felszín alatti Vizekért Alapítvány - VITUKI. Budapest.

Jakucs, L. 1951: Vízföldtani vizsgálatok a Gömöri-karszton (Hydrogeology analysis in Gömör-Karst). - Földtani Közlöny, 81, pp. 442-445.

Kessler, H. 1938: Az Aggteleki-barlangrendszer hidrográfiája (Hydrography of the Aggtelek cave system). - Földrajzi Közlöny, 66, pp. 1-30.

Norusis, M.J. 1993: SPSS for WindowsTM. - Professional StatisticsTM. Release 6.0, SPSS Inc. USA, $385 \mathrm{p}$.

Telbisz, T., T. Vigassy, L. Zámbó 1999: Variances of karst corrosion on the basis of differences in the solution of Ca- and Mg-carbonates. - In: Bárány-Kevei, I., J. Gunn (Ed): Essays in the Ecology and Conservation of Karst. - Acta Geographica 36. (Spec. Issue), Szeged, pp. 193-200.

Vass, I. 1831: Az Agteleki barlang leírása fekte területével, talprajzolatával és hosszába való átvágásával. - két táblán, Pesten nyomtatta Landerer

Zámbó, L., D. Ford, T. Telbisz 2002: Baradla-barlangi cseppkőkoradatok a késô-negyedidőszaki klímaingadozások tükrében (Age data of speleothems in the Baradla Cave, with reference to climatic oscillations in the Quaternary period). - Földtani Közlöny, 132/Különszám, pp. 231-238. 